\title{
Partisan Politics and Institutional Choice in Public Bureaucracies: Evidence from Sweden
}

\author{
Mikael Holmgren \\ PluriCourts \\ University of Oslo \\ mikael.holmgren@jus.uio.no
}

\begin{abstract}
Assuring successful delegation from elected representatives to unelected bureaucrats is an essential part of contemporary democratic governance and, to do so, politicians typically rely on administrative institutions that limit the feasible set of policies that bureaucrats can pursue. In this article, I suggest that precisely because administrative institutions are instruments of political control, partisan conflict over public policies often generates partisan conflict over institutional arrangements. To assess the empirical merits of this proposition, I analyze a unique dataset with detailed information on all administrative agencies enacted in the executive administration of Sweden between 1960 and 2014. I find that agencies are considerably more likely to be terminated when there is a conflict of interest between the enacting and sitting coalitions. Consistent with positive political theories of bureaucratic delegation, I conclude that partisan politics colors not only the substantive contents of public policies, but also the organization of the administrative state.
\end{abstract}

In all modern democracies, elected representatives routinely delegate public authority to unelected bureaucrats. As Weber (1978) famously observed, this arrangement holds both promises and pitfalls. The great advantage of bureaucracy is that elected representatives can draw on the expertise and abilities of others to prepare, formulate, and implement the law of the land. The dilemma is that bureaucrats can be just as motivated by gain, fame, and policy fortune as any other public official. To understand how modern democracies work, one must accordingly understand their bureaucracieshow they are designed, the functions that they serve, and whose interests they represent. 
In recent years, an extensive literature in American politics has suggested that political leaders often respond to the possibility of a runaway bureaucracy by strategically manipulating administrative institutions (e.g. Epstein and O'Halloran 1999; Huber and Shipan 2002; Kiewiet and McCubbins 1991; Lewis 2008). On this view, institutional choice in public bureaucracies is best understood, not as reflecting a particular cultural or historical legacy, but as an ex-ante agreement among political leaders made to safeguard against opportunistic behavior ex-post. As long as politicians believe that bureaucrats will act in their interest, they will delegate generously and leave the details to be filled in at the agency's discretion. If they were to suspect that delegated powers might be used against them, on the other hand, they will write detailed instructions, screen and select for loyal personnel, monitor agency activities, mandate regular reporting requirements, enfranchise affected constituencies, embed veto points in administrative procedures, and direct appropriations. In this way, the staff, structure and process of the bureaucracy emerges, not as a set of impartial administrative institutions, but as a vehicle for advancing and protecting the partisan interests of the political coalitions responsible for its enactment.

In this article I analyze institutional choice in public bureaucracies, focusing on the effects of partisan shifts in government. A less recognized implication of the positive political theory of administrative design is that, when a political principal first sets out to control her bureaucratic agents, she is unlikely to be so fortunate as to start from a blank slate. Rather, each new generation of political leaders will inherit an administrative state jointly designed by their predecessors. And whereas some past governing coalitions will undoubtedly have had objectives congruent with those currently in power, others may well have been guided by quite different preferences and priorities (Moe 1989, 1990). If political decisions about administrative institutions are truly motivated by a desire to advance political agendas, then as the partisan composition of the dominant governing coalition changes, we should also generally expect the new parties in power to be particularly motivated to realign the administrative institutions that have been imposed by their political opponents. That is to say, all of the various appointments, appropriations and procedures that are authorized on behalf of the ruling political elite should be particularly at risk of being subverted when there is a conflict of interest between the enacting 
governing coalition and the sitting governing coalition. Conversely, the bureaucracy should appear particularly robust as long as the enacting and sitting coalitions have common interests.

To assess the empirical merits of this proposition I examine the termination rates of all administrative agencies enacted in the Swedish executive bureaucracy between 1960 and 2014. Although many contemporary democracies employ universal rules about administrative process that apply to all bureaucratic decisions - such as rules about the sequence in which administrative matters must be considered, the information that bureaucrats must assemble, take into account and reveal to others, or the standards by which arguments, plans and promotions must be evaluated (e.g. McCubbins, Noll and Weingast 1987, 1989) - it is within individual agencies that such rules are instantiated in practice. Moreover, universal rules about administrative process are often complemented by rules that apply only to a sub-set of agencies, and structural rules that assign authority and responsibility are almost always imposed on a case-by-case basis, for instance, through decisions about agency jurisdictions, management forms, executive appointments, and budgets. When political leaders decide which agencies are allowed to operate in a polity, they are also deciding what sort of administrative institutions should constitute the bureaucracy. Modelling these decisions empirically thus enables an indirect evaluation of how the institutional composition of the bureaucracy is affected by changes in the political environment. I show that more than half of all Swedish agencies enacted over the past half century have been terminated and, using hazard models, that the risk of termination increases considerably following partisan shifts in government.

The article contributes to a number of ongoing debates in comparative public administration. While the US federal bureaucracy has recently been found to be surprisingly plastic and reorganized by the parties in power with some frequency (e.g. Lewis 2002, 2004; Selin 2015), little is currently known about how or even whether these results generalize to other polities (but on the United Kingdom, see e.g. Bertelli and Sinclair 2016; Greasley and Hanretty 2016; James et al 2015). At the same time, many public administration scholars remain insistent in their claims that institutional choice is best understood as a function of distinct national administrative cultures and traditions, not of general political factors (e.g. Christensen and Laegreid 2003; Painter and Peters 2010; Pollit and Bouck- 
aert 2004). Yesilkagit and Christensen (2010, 69), for example, conclude that, while ideological conflicts may well have guided the development of the US federal bureaucracy, "institutional design in parliamentary systems tends to be more or less independent from political factors." The results presented in this article suggest that partisan politics is one important part of the explanation for why administrative institutions can sometimes appear remarkably stable and at other times strikingly frail. Future studies of institutional choice in the parliamentary democracies of Europe would accordingly do well to further investigate how political considerations can filter into the staff, structure and process of public bureaucracies (e.g. Bach and Veit 2017; Dahlström and Holmgren 2017; Ennser-Jedenastik 2016).

The remainder of the article proceeds as follows. I first explain in more detail how the institutional foundation of public bureaucracies can be endogenously generated by political struggles over the exercise of public authority. Next, I provide background information on the Swedish case, present the dataset, introduce the covariates included in the empirical models, and discuss methods. I then submit the results. The final section concludes by considering the implications of the findings for the literature on delegation and administrative design and avenues for future research.

\section{Delegation and the Theory of Political Control}

Reigning positive political theories of administrative design are deeply rooted in organizational economics, drawing particularly from agency theory and transaction cost economics (Moe 1984, 2012). From this perspective, the relationship between politicians and bureaucrats is understood as a principal-agent problem, with an analytical focus centered on what -if anything - a given governing coalition can do to ensure that its policies are faithfully carried out by the bureaucracy. The problem is that bureaucrats typically possess a vast range of private information, owing to their superior expertise and other knowledge that may be acquired either before or on the job, and the now standard answer is that politicians can respond by imposing decision procedures, incentive systems and monitoring mechanisms that constrain the feasible set of policies that bureaucrats can pursue. By strategically controlling the rules of the game, in other words, politicians can compensate for their informational disadvantage and steer bureaucrats towards the objectives they desire. 
In this most basic sense, the outlook is of course not so different from a traditional Weberian understanding of public administration. Modern bureaucracies come staffed with highly skilled policy professionals who should be able to safely guide the implementation of public policies; however, the very expertise and resources that make modern bureaucracies the effective machines that they are also present bureaucrats with opportunity to usurp public authority for their own ends (e.g. Downs 1967; Lowi 1978). As Weber (1978) observed, bureaucrats are typically just as motivated by status and power as any other public official. And if left unchecked, they will seek to further their own authority, develop relations with influential interest groups, and veil their information and actions from outside criticism. Where there is opportunity, resources will be invested to acquire additional resources, and the more time an agency has to build its assets, the more durable it becomes. An implication of this traditional view is that unfortunate political leaders may just one day find themselves governing an unresponsive army of immortals, as Kaufman (1976) put it, with little hope of changing course.

What distinguishes contemporary political theories from the old is the notion that, even when faced with severe informational asymmetries and conflicts of interest, political leaders need not be helpless; rather, they can defend themselves by designing administrative institutions that alter the incentives and opportunities of bureaucrats to take actions against their interests. The earliest attempts at explicating the nuts and bolts of this process focused on ex-post controls - that is, on institutions that operate after bureaucrats take action. By monitoring behavior, rewarding compliance, and punishing defection, politicians can continuously constrain bureaucratic decision-making and protect their policies from being subverted during implementation. As long as agency decisions can be credibly sanctioned, bureaucrats must anticipate the response of politicians and accommodate their interests, or run the risk of seeing their programs curtailed and careers ended (McCubbins and Schwarz 1984; Moe 1985; Weingast and Moran 1984). A problem with active oversight, however, is that it imposes costs not only on the agent, but also on the principal who performs it. And in the shadow of endemic collective action problems, sanctions may not always be credible. For these reasons, politicians will often find it more attractive to promote compliance ex-ante through strategic decisions about procedures, organization, and personnel systems - that 
is, institutions that operate before bureaucrats take action. Inventive use of administrative appointments, structures and processes can ameliorate both informational asymmetries and conflicts of interests by, for instance, demanding that bureaucrats reveal their policy ambitions in advance, take specific kinds of constituency or professional information into account, and shoulder the burden of proof, as well as by enfranchising favored groups and granting special interests selective access to agency decision-making (Calvert, McCubbins and Weingast 1989; McCubbins, Noll, and Weingast 1987, 1989). As long as political leaders choose an appropriate combination of institutions, the bureaucracy will proceed on autopilot, programmed from the outset to pursue the partisan interests of the political coalitions in power at the time of enactment.

The literature dealing with the perils of "bureaucratic drift" and the institutional solutions that politicians can deploy to mitigate it has made marginal advances over time (e.g. Bendor, Glazer and Hammond 2001; Epstein and O'Halloran 1999; Huber and Shipan 2002; Miller 2005; Moe 2012), contributing notably with more nuanced perspectives on the inherent trade-off between political control and bureaucratic expertise (e.g. Bawn 1995; Bertelli and Lewis 2008; Gailmard and Patty 2012). But the core that was borrowed from the new economics of organization some thirty years ago with its focus on conflicts of interest and asymmetric information remains largely intact. Although hidden information and hidden action will always leave some room for bureaucratic shirking and slippage, democratic governments usually have a variety of instruments at their disposal to counteract non-compliance and assure that their policies do not drift too far from target.

\section{Partisan Politics and Institutional Choice}

A complicating implication of the notion that administrative institutions can be designed to at least partly determine policy outcomes, however, is that the choice of such institutions should then also tend to attract the same kind of political disagreements as the choice of public policies does (Horn and Shepsle 1989; Moe 1989, 1990; Shepsle 1992). If different administrative institutions lead to different policy outcomes, and different policy outcomes are preferred by different political coalitions, then different political coalitions should also prefer different administrative institutions. As Riker (1980) observed, preferences over institutions tend to be inher- 
ited from preferences over policies. And if a given governing coalition is dissatisfied with a particular set of policy outcomes, they may be able to move policy in their preferred direction by reorganizing the institutions that operate in the relevant policy domain.

When should we expect politicians to be the most dissatisfied with policy outcomes, and thus face the greatest incentive to invest in reorganizing their bureaucracies? If the positive political theory of administrative design is true, then they should typically be the most dissatisfied with policy outcomes when they face a set of administrative institutions that have been designed by their political opponents. As long as the policy preferences of the enacting and sitting coalition converge, an administrative institution designed to advance and protect the interests of the former will also serve the interests of the latter, encouraging preservation. If the policy preferences of the enacting and sitting coalition diverge, on the other hand, then an administrative institution designed to serve the interests of the former will be in conflict with the latter, encouraging subversion. Substantively, preservation can, for example, translate into leaving the budget, jurisdiction, and leadership of an agency intact. By contrast, subversion can take the form of cuts in appropriations (Berry, Burden and Howell 2010), restrictions to an agency's authority and responsibilities (Huber and Shipan 2002), or new screening and selection procedures for key personnel (Lewis 2008). The single most consequential way in which politicians can intervene in bureaucratic activities, however, is of course by terminating the entire operation (Lewis 2002, 2004). When political leaders imprint their policy priorities in the institutional foundation of the bureaucracy, they are also effectively creating incentives for the next generation of political leaders to amend, displace, and replace that foundation.

Of course, the political actors responsible for creating an agency need not leave it unprotected. Much like how enterprising political leaders can design agencies with a view towards constraining opportunistic bureaucrats, they can also design agencies with a view towards constraining opportunistic political competitors (e.g. Lewis 2003; Selin 2015; Wood and Bohte 2004; but cf. de Figueiredo 2002). For each potential instrument of political influence, there also exists a corresponding instrument to thwart that influence: tenure protection can counteract appointment powers; placing agencies outside the organizational purview of ministerial departments can obstruct day-to-day oversight; granting agencies the right to collect and 
spend their own funds can make them less dependent on political appropriations; and so forth. In addition to embedding agencies within protective formal frameworks, inventive agency designers can also seek to increase the costs of future interventions by empowering social groups with a concentrated stake in the agency's continued maintenance (Moe and Caldwell 1994; Patashnik 2003). They would adversely affect their own opportunities for ex-post control in the process. But since they would also have the first-mover advantage, the loss of influence tomorrow may well sometimes be a reasonable price to pay in exchange for greater influence today.

What can new generations of political leaders do to advance their own agendas if the agencies they rely upon for policy implementation were to be both designed to serve conflicting interests and insulated from political control? The answer is that they must find a way to either undo or work around the constraints that previous generations of political leaders have imposed upon them. Even the most cumbersome of institutional arrangements, such as the combination of separation of powers and checks and balances at the political level with universal civil service restrictions at the administrative level, typically do not block every conceivable route to manipulate the bureaucracy. Reversion strategies can both be formally specified ex ante as part of a given arrangement, but also developed informally ex post through learning and experience. In the US, for example, an incoming President need not passively accept the administrative frameworks authorized by Congress and previous Presidents; instead, they can strike out on their own and create new agencies and positions (Howell and Lewis 2002; Lewis 2008). Similarly, in the UK, if the governing parties were ever to find themselves systematically disadvantaged by the current crop of agencies, then they can try to reshape those agencies to their own advantage (Bertelli and Sinclair 2016). As Shepsle (2008) points out, rather than allow for no discretion, real institutions tend to allow for "costly discretion" - that is, discretion which is costly enough to exercise that defection will not be an everyday occurrence, but not so costly as to completely prevent a decisive coalition from adjusting the institutional machinery in case of contingencies. Whether they will ever attempt to do so, however, depends on whether the expected benefits are worth the costs.

In sum, we should generally expect the robustness of public bureaucracies to depend upon the ideological relations between the enacting and sitting coalitions: The more the policy preferences of the enacting and 
sitting coalition diverge, the greater the incentive for institutional subversion; and the more similar are the policy preferences of the enacting and sitting coalition, the greater the incentive for institutional preservation. At the same time, however, we should not expect the bureaucratic status quo to be perfectly or immediately adjusted to reflect the interests of its new masters - indeed, the theory suggests that, precisely because bureaucracies are designed to advance political agendas, establishing control over bureaucratic decision-making is likely to require non-trivial amounts of time, effort and resources. Learning about the benefits of an intervention carries its own set of costs (Carpenter and Lewis 2004). And before an intervention becomes a live option, the ruling political elite will have to overcome all the usual collective action problems associated with democratic coalition governance (Lupia and Strøm 2008). Moreover, because some administrative institutions are installed to prevent agency losses from occurring rather than to assure the selection of any particular policy, they may well be of use to more than one partisan coalition, thereby generating a certain degree of stickiness over time (Kiewiet and McCubbins 1991, 34-37). But, on the margins, Riker's (1980) observation that institutions are little more than "congealed tastes" should carry force: when one governing coalition is replaced by another, the latter will seek to reshape the bureaucracy to its own advantage, just like the ones that preceded them.

\section{Data, Covariates and Methods}

To assess how changes in the partisan composition of governing coalitions can affect institutional choice in public bureaucracies, I examine the termination rates of all administrative agencies enacted in the Swedish executive bureaucracy between 1960 and 2014. Though there are of course numerous ways in which political leaders could attempt to manipulate the institutional composition of the bureaucracy, agency terminations have the dual benefit of being both substantively important and cleanly observable. By revoking the powers of an agency wholesale, governments can displace the administrative frameworks that were created by their opponents, reshuffle authority, personnel and resources, and intervene directly in the implementation of public policies. Rather than treat the termination of administrative agencies as something special and unique, I thus simply treat it as a special case of institutional choice: why do political actors settle upon one 
set of rules to govern their future interactions when they could, in principle, choose some other set of rules?

In this context, the Swedish case features a number of notable constitutional characteristics. In contrast to the US system of separate powers, the Swedish constitution defines an almost ideal-typical singular chain of delegation and accountability, running from the people, acting as the ultimate principal, through the legislature, executive, and bureaucracy (Bergman 2003). The winning legislative coalition appoints the prime minister, who, in turn, is free to create cabinet departments and appoint individual ministers as they see fit. Because the executive arises out of the legislature in this way, both branches of government are typically controlled by the same parties (similarly to the British case, see e.g. Moe and Caldwell 1994). During the period under study, the main contenders for government formation have been the Social Democratic Party, which dominated Swedish politics for most of the post-war period, and a liberal-conservative multi-party coalition, which first emerged as a proper alternative in the late 1970s. The resulting political order is a system that closely resembles a pure-form parliamentary democracy, in the sense of Strøm (2000), with two ideological blocs competing for monopoly rights on public authority.

The relatively simple parliamentary chain of delegation that is at the heart of the Swedish constitution has a number of implications for the present study. The general lack of competition between the legislative and executive branches means that whoever manages to form a government can usually lay claim to the entire legislative process - including any past decisions relating to bureaucratic organization. As a consequence, whatever administrative frameworks the blocs decide to formalize, the other bloc will have the opportunity to undo following partisan shifts in government. Agencies, for instance, are almost always authorized by executive order and accordingly open to political contestation. Because the legislature and executive are both controlled by the same parties, they do not struggle over who should control the bureaucracy or what sort of agency designs to pursue.

However, not all aspects of bureaucratic organization are part of the ordinary legislative game. Swedish political leaders have managed to embed a number of core rules regarding the bureaucracy's overarching structure and process in the constitution, which offers a base level of protection from political opportunism that standard legislation and executive 
orders cannot match ${ }^{1}$. The most important of these are a set of rules that restrict the ability of individual ministers to manipulate the composition and decisions of agency personnel (see e.g. Ahlbäck öberg and Wockelberg 2015; Pierre 1995). The Swedish Instrument of Government explicitly stipulates that the government takes all decisions collectively at formal cabinet meetings (ch. 7, art. 3), that all bureaucrats are appointed on meritocratic principles (ch. 12, art. 5), and that all agencies enjoy formal independence in the sense that no one but the agency itself is allowed to dictate how the agency should rule in specific cases or implement the law (ch. 12, art. 2). Insofar as the cabinet ministers want to direct agency decision-making, their only constitutionally sanctioned routes are through appointees, policy-relevant legislation or executive orders, and annual appropriations - all of which must be approved by the cabinet as a whole before gaining traction. Unlike in the US, moreover, the power of appointment is limited to top level executive positions, such as agency heads and management boards, and all appointees are protected from arbitrary dismissal through fixed-term contracts. By constitutional design, Swedish governments are thus to check individual agencies primarily by controlling their decision-making environment, not by managing their personnel and day-to-day operations ${ }^{2}$.

These constitutional limitations on ministerial discretion matter both because they determine between which actors the relevant principal-agent relationship is to be found and because they provide incentives for certain kinds of political interventions above others. While individual ministers can always attempt to work around the formal frameworks of government in their quest for control over the policy process, the formal ban on ministerial rule also ensures that there are clear risks associated with becoming too closely involved in the decisions, pay or tenure of individual bureaucrats. Were they to act as a collective, on the other hand, the cabinet ministers can typically enact, terminate and reorganize agencies as they please with little concern for legal repercussions or parliamentary objec-

\footnotetext{
${ }^{1} \mathrm{~A}$ constitutional amendment requires an identical decision to be passed by a parliamentary majority in two electoral terms, with an electoral term usually being four years long (Sweden had three-year terms between 1970 and 1994).

${ }^{2}$ To get a better sense for what the constitutional division of labor between politics and administration means in terms of employment relations, note that the Government Offices (which includes the ministerial departments) only employs about two percent of all state personnel; the rest are employed by the agencies and thus constitutionally protected from ministerial interference.
} 
tions. In short, the accountability structure that exists between politicians and bureaucrats in the Swedish case is deliberately designed as a relationship between collective actors - cabinets and agencies - and to the extent that politicians want to punish bureaucrats for non-compliance, they will generally have to apply their retribution as a collective on a collective, such as by mandating that an agency cease its operations in full or by otherwise circumscribing its policy discretion ${ }^{3}$.

\section{Data}

The dataset was primarily compiled using Sveriges statskalender, which is a compendium of operative public organizations and employees published annually by the Swedish government since 1812. The list includes a diverse set of public organizations, such as universities, county administrative boards, museums, government owned businesses, police authorities, regional archives, regulatory commissions, and general public service agencies, and excludes a small number of agencies accountable only to the parliament as well as judicial agencies such as the courts ${ }^{4}$.

To transform the compendium into analyzable data, each agency has been documented as a counting process that runs from the year of enactment until the year of termination, with one observation for each calendar year that an agency remains in operation. An agency is considered enacted when its operations are authorized either by statute or executive order, formally referred to as an agency instruction, and terminated when it has its authorization wholly revoked ${ }^{5}$. The instruction typically focuses on the

\footnotetext{
${ }^{3}$ Furthermore, because Swedish political leaders rely largely on very general, overarching constitutional principles to constrain political opportunism, many of the formal "hard-wiring mechanisms" that have preoccupied much of the American literature on agency insulation (see e.g. Lewis 2004; Selin 2015) do not vary either within or between Swedish agencies. Instead, where they apply, they apply equally to the entire bureaucracy. While this means that I cannot assess the empirical merits of a number of central arguments in the literature, it also means that an important source of heterogeneity is held constant throughout the statistical analyses, discussed further below.

${ }^{4}$ The short list of statutory agencies accountable only to the parliament mainly consists of a number of smaller committee-like organizations dealing with matters such as party financing, remuneration for members of parliament, and electoral districts. In addition, however, the list also includes three prominent regulatory agencies: the Swedish National Audit Office; the Parliamentary Ombudsman; and the Central Bank of Sweden. These latter three agencies have their basic organizations defined in the constitution, which makes them considerably more difficult to reorganize than other agencies.

${ }^{5}$ Of course, an "agency termination" in this formal sense does not necessarily mean that delegated powers go up in smoke; it simply means that a particular principal-agent contract no longer holds. While outside the scope of this article, a fruitful line of inquiry for future research would be to examine post-termination
} 
management form and overall tasks and obligations of an agency, but in some cases it can also specify in greater detail whether it should include any advisory boards, regional offices, standing committees, or other sections. Although such sub-units can sometimes act relatively independently, here they are uniformly treated as part of the parent agency as long as they do not receive their own unique instruction. The Swedish Security Service, for example, was formally established as a section under the Swedish National Police Board in 1989, but since it did not receive its own instruction until 2002, it is not registered as a unique agency during the period 19892001. Similarly, the Swedish Enforcement Authority has regional offices in a number of major cities, but because those offices are all defined in the same instruction, they are treated as part of the same agency. In total, the sample includes 8202 yearly interval observations from 456 unique agencies with 269 observed terminations. The median survival time is fifteen years, with the shortest duration lasting for one year and the longest for fiftytwo years. The dataset ends after 2014, leaving forty-one per cent of the agencies right-censored (i.e. still in operation when observation ceased).

Figure 1 shows the total number of agency creations and terminations by calendar year, with the ideological affiliation of the government included for reference. The positive count denotes agency creations, while the negative count denotes agency terminations. On average, Swedish governments have authorized new agencies at a fairly consistent pace during the observed period, although with some notable ups and downs along the way. The average number of creations in the first half of the period is nine per year while the average for the second half is eight per year, with a top count of twenty-one creations in 1977. By contrast, most of the agency terminations occur during the second half of the period. The average number of terminations in the first half of the period is four per year while the average for the second half is nine per year, with a top count of twenty-six terminations in 2008. While the blocs have similar highs and lows on both event counts, the liberal-conservative bloc has been the more industrious one when it comes to abolishing agencies. The Social Democratic Party has been in power for 69 percent of the period and is responsible for 68 percent of the creations and 51 percent of the terminations. The liberalconservative bloc has been in power for 31 percent of the period and is

outcomes and trace how governments go about in redistributing public authority (since the resources and functions of terminated agencies will typically be transferred to other agencies, either new or old). 


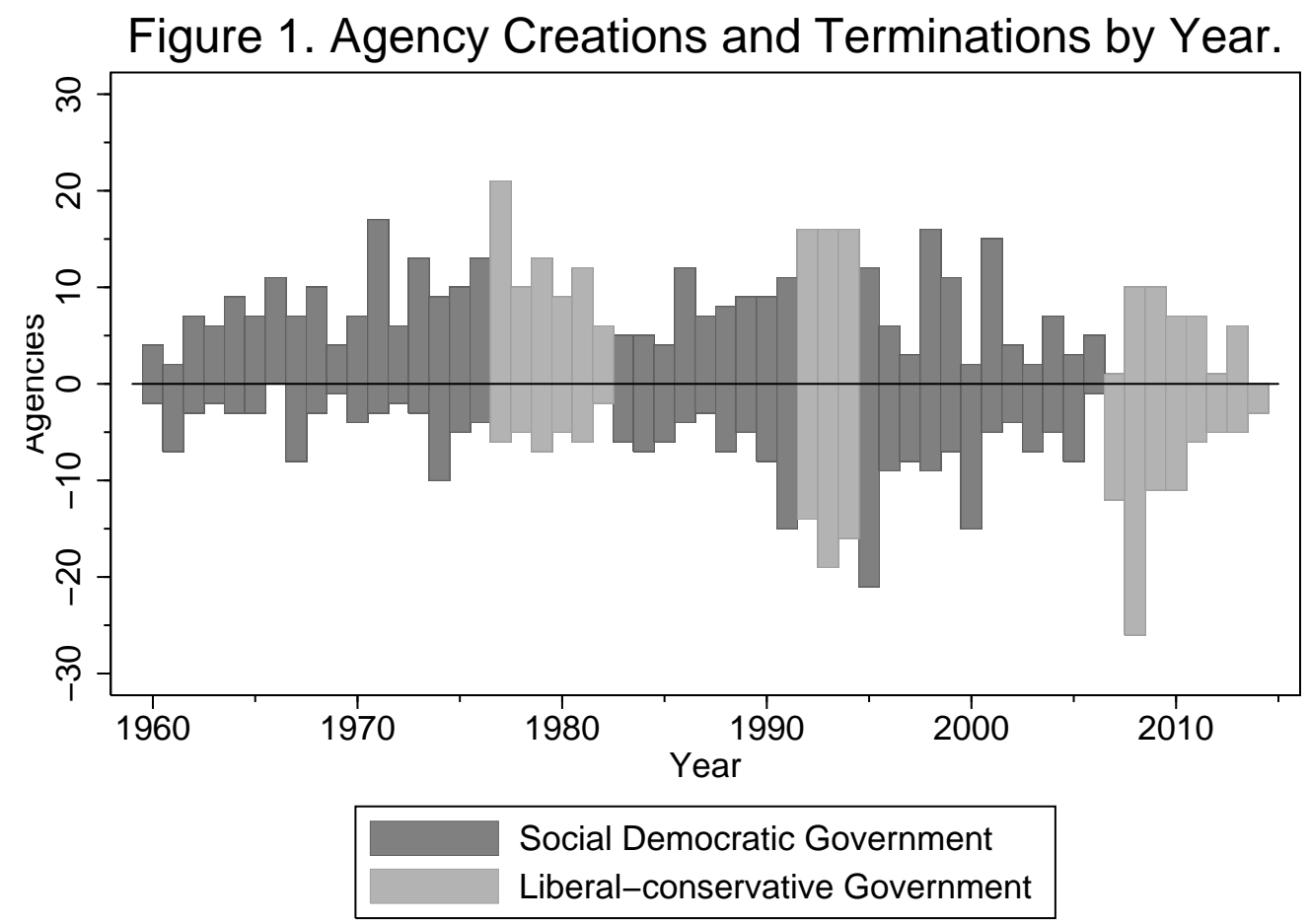

responsible 32 percent of the creations and 49 percent of the terminations. The discrepancy in termination counts could of course be due to intrinsic differences between the blocs. In light of the theory, however, there is also an alternative explanation on the table: the liberal-conservative bloc may appear more inclined to abolish agencies not because they prefer "small government" per se, but because the Swedish bureaucracy just so happens to come equipped with a disproportionally large amount of agencies created by the Social Democratic Party. Had there been a more equal distribution of social democratic and liberal-conservative agencies from the outset, the liberal-conservative parties might have faced quite different incentives. Conversely, the fact that the Social Democratic Party appears less inclined to terminate agencies (proportionally speaking) need not imply that they have an intrinsic preference for large bureaucracies. Instead, it could be a consequence of the over-representation of social democratic agencies. In either case, the graph clearly shows that the Swedish bureaucracy is not a static construct, but a population of administrative units that experiences both regular additions and subtractions. 


\section{Covariates}

The main explanatory factor of interest is ideological conflict between the coalition responsible for designing an agency and the coalition with the right to hold the agency to account. As argued above, if administrative institutions are simply instruments of political control, then whatever political disagreements that might exist between competing partisan coalitions should also be reflected in the politics of institutional choice. To construct a measure of the level of conflict between the enacting and sitting coalitions, I first match each agency to attributes of the political parties that were in power at the time of enactment; then, for each subsequent year that an agency was in operation, I examine how those attributes compare to the attributes of the parties in power during that year. As there are a number of other factors that could make agency survival more precarious, I also construct two sets of covariates respectively intended to adjust for heterogeneity in agency and cabinet characteristics (see table 1 for summary statistics). I then use hazard models to estimate the effects of partisan shifts in government on agency termination rates ${ }^{6}$.

I rely on two measures to account for conflicts of interest between the enacting and sitting coalitions. First I construct a binary covariate, party conflict, denoting whether the cabinet responsible for creating an agency has the same ideological affiliation as the sitting cabinet, with the creator and incumbent respectively being either the Social Democratic Party or a liberal-conservative multiparty coalition. I assume that when political leaders design agencies, they do so strategically to advance their own agendas. Cabinet turnover since the time of enactment increases the level of ideological conflict between an agency and the political incumbent because both blocs see the creations of the other as representing interests opposed to their own. I expect that agencies will be more susceptible to termination when accountable to an ideological opponent of the agency creator than when accountable to an ideological ally of the agency creator.

Second, as an alternative specification I also use data from the Comparative Manifestos Project (Volkens et al 2015) to construct a continuous measure of ideological conflict, policy conflict, denoting the ideological dis-

\footnotetext{
${ }^{6}$ The range of covariates that could plausibly cause both partisan shifts in government and an increase in agency termination rates is limited. However, as unmeasured risk factors can sometimes bias hazard models even if uncorrelated with the observed covariates (as is well known; see e.g. Lancaster 1979), it is important to also consider potentially influential non-confounders.
} 
Table 1. Summary Statistics.

\begin{tabular}{lccccc}
\hline Covariates & Obs. & Mean & Std. Dev. & Min. & Max. \\
\hline Party Conflict & 8192 & 0.43 & 0.50 & 0 & 1 \\
Policy Conflict & 8192 & 2.54 & 2.10 & 0 & 10.50 \\
Rulemaking & 8192 & 0.51 & 0.50 & 0 & 1 \\
Oversight & 8192 & 0.19 & 0.39 & 0 & 1 \\
Adjudication & 8192 & 0.26 & 0.44 & 0 & 1 \\
Management Board & 8192 & 0.47 & 0.50 & 0 & 1 \\
Liberal-conservative & 8192 & 0.38 & 0.49 & 0 & 1 \\
Legislative Seats & 8192 & 45.11 & 6.67 & 11.17 & 53.65 \\
New Term & 8192 & 0.28 & 0.45 & 0 & 1 \\
Economic Growth & 8192 & 2.22 & 2.23 & -5.00 & 6.80 \\
\hline
\end{tabular}

tance between the enacting and sitting cabinets. For the party covariate to be a valid indicator of ideological conflict, the parties in power must have relatively stable policy positions over time. Yet, the Social Democratic Party has had a number of well-known disputes between socialist and liberal factions over the years (Huber and Stephens 2001), and the leaders of the largest party in the right-wing bloc, the conservative Moderate Party, have recently been keen to distance themselves from their predecessors (Lindbom 2008). If there is substantial over-time variance in policy preferences within the blocs, party turnover may make for a poor indicator of the actual level of conflict. There is no completely satisfactory solution to this problem in the absence of more direct preference measures (e.g. Clinton et al 2012), but the manifesto data does provide a useful complement to the binary covariate by allowing for cabinets with the same party composition to have different policy priorities, although with the caveat that manifestos may also be more indicative of issue salience than of true ideology. The covariate is based on the policy positions of the prime minister's party and captures the absolute distance between the left-right position of the enacting and sitting cabinets. Analogously to the party covariate, I expect that agencies will become more susceptible to termination as the ideological distance between the enacting and sitting cabinet increases ${ }^{7}$.

The party and policy covariates are both grounded in the assumption that agencies to some extent reflect the ideological characteristics of the political coalitions that authorized their operations. While this assump-

\footnotetext{
${ }^{7}$ The original policy scale ranges from -100 to 100 . For readability, I have rescaled this measure into a variable ranging from -10 to 10 .
} 
tion is difficult to prove, it is supported by substantial historical evidence in the Swedish case (Dahlström and Niklasson 2011; Jacobsson, Sundström and Pierre 2015). Rothstein (1996), for example, details how the Social Democratic Party systematically manipulated the screening and selection procedures of the National Labour Market Board throughout the postwar period in order to assure that the agency was staffed by civil servants loyal to social democratic policy objectives. As Pierre (1995) observes, because many of the affected positions were not strictly speaking political appointees that could be subsequently replaced, but tenured senior officers, the sort of politicization efforts emphasized by Rothstein (1996) and others is also particularly prone to generate policy disagreements between politics and administration when the government changes hands (for examples, see e.g. Ahrland 1983; Levin 1983). More generally, recent survey experiments have also shown that Swedish citizens are much more likely to favor decision-making procedures that make them into policy winners (Esaiasson et al 2016). While I proceed by assuming that Swedish political leaders design agencies to advance their own agendas, then, I also stress that this is a defensible position.

To adjust for heterogeneity between agencies, I first include three binary covariates denoting whether an agency has regulatory functions. Greasley and Hanretty (2016), for example, argue that politicians commonly grant regulatory agencies unusually high levels of policy discretion in order to ameliorate commitment problems in the public sector. Since agency termination is nothing more than the ultimate act of political control, unusual levels of policy discretion may also translate into unusual durability. Rule-making denotes whether an agency has the right to regulate some area of human activity, oversight whether an agency has the right to police regulations, and adjudication whether an agency has the right to adjudicate regulatory interpretations (e.g. disputes between stakeholders). Second, as a proxy for agency size, I also include a binary covariate, management board, denoting whether an agency has a board structure. Large budgets, many employees, and a broad set of functions can make agencies more difficult to terminate (Kaufman 1976) and, in Sweden, management boards are typically reserved for agencies with extensive fiscal responsibilities. Additionally, as the boards are also one of the primary mechanisms for stakeholder representation, they should also tap into some of the variation in interest group salience (Moe and Caldwell 1994). 
To adjust for heterogeneity between sitting cabinets, I first introduce a continuous covariate, economic growth, denoting the annual percent change in the real gross domestic product. On the one hand, government reorganization is almost always justified as a strategy for cost containment but, on the other hand, government reorganization is also itself a costly activity (Carpenter and Lewis 2004). Second, since the blocs may have different preferences concerning the appropriate size of government, I include a binary covariate, liberal-conservative, denoting whether the cabinet is controlled by a liberal-conservative coalition ${ }^{8}$. Third, in order to account for the possibility that governments may front load their most radical reforms, I include a binary covariate, new term, denoting whether it is the first year of a new electoral term. Fourth and finally, since cabinets that are only weakly supported by the parliament may be less inclined to disrupt the status quo than those that enjoy strong support, I also include a continuous covariate, legislative seats, denoting the net share of legislative seats under control by the parties in the sitting cabinet.

\section{Methods}

I implement the covariates through a series of Cox regressions, which is a semi-parametric technique for estimating time-to-event that combines the proportional hazards duration model with the partial likelihood method for estimation (Box-Steffensmeier and Jones 2004). The dependent variable is the hazard rate, which in this case loosely translates into the probability that an agency will be terminated in a given year, conditional on having endured up until that point. The main benefit of Cox regression is that it leaves the functional form of the baseline hazard unspecified (i.e. the reference category when all covariates in the model are at zero), enabling estimation of covariate effects without strong parametric assumptions about the underlying probability distribution of event occurrence. Additionally, Cox regression is also flexible enough to handle time-varying covariates, time-dependent coefficients, and right-censoring with relative ease, making it the natural starting point for modelling complex event histories.

To assure the robustness of the results, I employ a number of extensions to the basic Cox model. First, I estimate models with shared ministry

\footnotetext{
${ }^{8}$ Because all social democratic governments in the sample are one-party governments while all liberalconservative governments are multi-party governments (save for a brief liberal one-party government in 1978), this covariate is also highly correlated with the number of parties in the cabinet $(\mathrm{r}=0.93)$.
} 
frailties. The logic behind these models is that some agencies may appear more "frail" than others simply because some ministries carry unobserved attributes that make them intrinsically riskier to be a part of than others. Agencies operating under the Ministry of Justice, for example, may well appear abnormally robust simply because no one would seriously dispute that modern states require law enforcement. Yet other policy areas may present more temporary challenges, causing a natural variation in termination rates between different portfolios. Such hidden risk factors can be modelled as a latent covariate, analogous to a random effect in linear hierarchical models (Hougaard 2000). The ministry frailties allow for coefficients to vary across ministries but, as with any random effect, they are also generally required to be independent of the observed covariates. This is a restrictive assumption, but less so than the assumption of complete homogeneity that underpins pooled models.

Second, I stratify the agencies by ministry. Although Cox regression leaves the functional form of the baseline hazard unspecified, whatever shape the hazard function does have, it is assumed to be the same across all subjects. With stratification, each ministry is allowed to have its own distinct baseline hazard, while coefficients are constrained to be the same across ministries. Analogous to fixed effects in linear models, this eliminates the influence from all unobserved, time-constant, ministry-level factors by collapsing them into the unspecified hazard function of each ministry (Allison 2009). The drawback is that, since stratified models only consider variation within cases, they are also prone to inflate standard errors and underestimate the effects of covariates that change slowly or only rarely over time.

Finally, I rely on scaled Schoenfeld residuals to assess the proportional hazards assumption for each individual covariate. There is no evidence of policy conflict having time-dependent effects using either a linear, logarithmic, rank or Kaplan-Meier transformation of follow-up times. However, there is some evidence that party conflict violates the assumption, and most noticeably so with a logarithmic transformation. To deal with this problem, I also estimate models where party conflict is interacted with a logarithmic representation of agency age (Licht 2011). This extension allows for the effect of partisan shifts in government to vary over time, although coefficients will naturally be constrained by the functional form of the time interaction. The results are reviewed below. 


\section{Results}

I present results from seven sets of Cox regressions. Model 1 to 4 focuses on the party conflict covariate, while model 5 to 7 focuses on the policy conflict covariate. Graphs of Cox-Snell and efficient score residuals suggest that the models generally fit the data well and with no problematic outliers, but as is often the case with hazard models, the fit is worse in the right-hand tail due to subjects dropping out over time. With this caveat, I report hazard ratios and standard errors for all models in table 2. A hazard ratio above one implies that a one-unit increase in the relevant covariate is associated with an increase in the rate of termination, while a ratio lower than one implies that termination rates are decreasing when the relevant covariate is increasing.

Consistent with theoretical expectations, I find evidence that changes in the partisan composition of governing coalitions over time can affect the survival chances of an agency. In all seven models, the estimated hazard ratios indicate that agencies are more likely to remain in operation when the enacting and sitting coalitions have common interests; conversely, agencies suffer greater risk of termination when there is a conflict of interest between the enacting and sitting coalitions. These results suggest that partisan politics is one important part of the explanation for why some agencies endure while others do not.

The point estimates are also of substantial size. In model 1 party conflict is associated with a hazard ratio of 1.60. This implies that, on average, the estimated risk of termination is 60 percent higher when an agency is accountable to a cabinet with a different ideological affiliation than the agency creator, for each year in an agency's life. This is a useful baseline estimate; however, as mentioned in the methods discussion, there is some evidence that the party covariate does not satisfy the proportional hazards assumption (i.e. that the effect remains uniform over time, irrespective of how long ago an agency was created). In model 2, 3 and 4, I therefore adjust for the possibility of time-dependence by interacting party conflict with a logarithmic representation of agency age. As an additional robustness check, in model 3 and $4 \mathrm{I}$ also include ministry frailties and stratification to adjust for the fact that agencies are hierarchically clustered within ministerial portfolios. These models provide more nuanced estimates than model 1, but are also somewhat more complicated to interpret since the regression outputs only display relevant coefficient values for 
Table 2. Partial Likelihood Estimates of Agency Hazards in Sweden, 1960-2014.

\begin{tabular}{|c|c|c|c|c|c|c|c|}
\hline Covariates & Model 1 & Model 2 & Model 3 & Model 4 & Model 5 & Model 6 & Model 7 \\
\hline Party Conflict & $\begin{array}{c}1.60 \\
(0.23)\end{array}$ & $\begin{array}{c}3.28 \\
(1.35)\end{array}$ & $\begin{array}{c}3.19 \\
(1.31)\end{array}$ & $\begin{array}{c}2.94 \\
(1.24)\end{array}$ & & & \\
\hline Party Conflict $\times \ln (\mathrm{t})$ & & $\begin{array}{c}0.73 \\
(0.12)\end{array}$ & $\begin{array}{c}0.75 \\
(0.12)\end{array}$ & $\begin{array}{c}0.79 \\
(0.14)\end{array}$ & & & \\
\hline Policy Conflict & & & & & $\begin{array}{c}1.08 \\
(0.03)\end{array}$ & $\begin{array}{c}1.08 \\
(0.03)\end{array}$ & $\begin{array}{c}1.09 \\
(0.03)\end{array}$ \\
\hline Rulemaking & $\begin{array}{c}1.11 \\
(0.15)\end{array}$ & $\begin{array}{c}1.11 \\
(0.15)\end{array}$ & $\begin{array}{c}1.14 \\
(0.16)\end{array}$ & $\begin{array}{c}1.10 \\
(0.16)\end{array}$ & $\begin{array}{c}1.08 \\
(0.15)\end{array}$ & $\begin{array}{c}1.10 \\
(0.15)\end{array}$ & $\begin{array}{c}1.07 \\
(0.14)\end{array}$ \\
\hline Oversight & $\begin{array}{c}0.80 \\
(0.14)\end{array}$ & $\begin{array}{c}0.81 \\
(0.14)\end{array}$ & $\begin{array}{c}0.73 \\
(0.13)\end{array}$ & $\begin{array}{c}0.68 \\
(0.13)\end{array}$ & $\begin{array}{c}0.80 \\
(0.14)\end{array}$ & $\begin{array}{c}0.73 \\
(0.13)\end{array}$ & $\begin{array}{c}0.67 \\
(0.12)\end{array}$ \\
\hline Adjudication & $\begin{array}{c}0.65 \\
(0.10)\end{array}$ & $\begin{array}{c}0.64 \\
(0.10)\end{array}$ & $\begin{array}{c}0.67 \\
(0.10)\end{array}$ & $\begin{array}{c}0.68 \\
(0.11)\end{array}$ & $\begin{array}{c}0.64 \\
(0.10)\end{array}$ & $\begin{array}{c}0.67 \\
(0.10)\end{array}$ & $\begin{array}{c}0.69 \\
(0.11)\end{array}$ \\
\hline Management Board & $\begin{array}{c}0.52 \\
(0.07)\end{array}$ & $\begin{array}{c}0.51 \\
(0.07)\end{array}$ & $\begin{array}{c}0.54 \\
(0.08)\end{array}$ & $\begin{array}{c}0.57 \\
(0.08)\end{array}$ & $\begin{array}{c}0.51 \\
(0.07)\end{array}$ & $\begin{array}{c}0.53 \\
(0.08)\end{array}$ & $\begin{array}{c}0.55 \\
(0.08)\end{array}$ \\
\hline Liberal-conservative & $\begin{array}{c}1.20 \\
(0.18)\end{array}$ & $\begin{array}{c}1.22 \\
(0.19)\end{array}$ & $\begin{array}{c}1.23 \\
(0.19)\end{array}$ & $\begin{array}{c}1.17 \\
(0.19)\end{array}$ & $\begin{array}{c}1.40 \\
(0.20)\end{array}$ & $\begin{array}{c}1.40 \\
(0.20)\end{array}$ & $\begin{array}{c}1.37 \\
(0.20)\end{array}$ \\
\hline Legislative Seats & $\begin{array}{l}1.01 \\
(0.01)\end{array}$ & $\begin{array}{l}1.01 \\
(0.01)\end{array}$ & $\begin{array}{c}1.01 \\
(0.01)\end{array}$ & $\begin{array}{c}1.01 \\
(0.01)\end{array}$ & $\begin{array}{c}1.01 \\
(0.01)\end{array}$ & $\begin{array}{c}1.01 \\
(0.01)\end{array}$ & $\begin{array}{c}1.01 \\
(0.01)\end{array}$ \\
\hline New Term & $\begin{array}{c}0.98 \\
(0.14)\end{array}$ & $\begin{array}{c}0.96 \\
(0.13)\end{array}$ & $\begin{array}{c}0.95 \\
(0.13)\end{array}$ & $\begin{array}{c}0.91 \\
(0.13)\end{array}$ & $\begin{array}{c}0.98 \\
(0.14)\end{array}$ & $\begin{array}{c}0.97 \\
(0.13)\end{array}$ & $\begin{array}{c}0.94 \\
(0.14)\end{array}$ \\
\hline Economic Growth & $\begin{array}{c}0.97 \\
(0.03)\end{array}$ & $\begin{array}{c}0.98 \\
(0.03)\end{array}$ & $\begin{array}{c}0.98 \\
(0.03)\end{array}$ & $\begin{array}{c}0.98 \\
(0.03)\end{array}$ & $\begin{array}{c}0.98 \\
(0.03)\end{array}$ & $\begin{array}{c}0.98 \\
(0.03)\end{array}$ & $\begin{array}{c}0.98 \\
(0.03)\end{array}$ \\
\hline $\begin{array}{l}\text { Ministry frailties } \\
\text { Ministry stratification }\end{array}$ & & & Yes & Yes & & Yes & Yes \\
\hline Agencies & 457 & 457 & 457 & 457 & 457 & 457 & 457 \\
\hline Observations & 8202 & 8202 & 8202 & 8202 & 8202 & 8202 & 8202 \\
\hline Terminations & 269 & 269 & 269 & 269 & 269 & 269 & 269 \\
\hline$\chi^{2}$ & 60.11 & 63.66 & 61.61 & 58.05 & 67.95 & 60.93 & 51.12 \\
\hline
\end{tabular}


the first year of observation - a quantity of rather limited interest. As can be seen in table 2 , although the point estimates for model 2, 3, and 4 indicate that agency termination rates are initially around 200 percent higher following partisan shifts in government, the negative interaction terms also indicate that the positive effect diminishes as agencies grow older. To provide a better view of the over-time variance, I also plot the relative hazard of party conflict in figure 2 based on model 3, with the raw event count as a backdrop. The $\mathrm{y}$-axis shows the relative hazard, while the $\mathrm{x}$-axis shows an agency's age. The long-dashed line traces the point estimate, while the short-dashed lines trace the confidence intervals. For reference, I have also included a connected line marking the null effect (relative hazard $=$ 1 ). The graph shows that, although the effect is quite sizable initially, the point estimate also decreases substantially over time and eventually hits the reference line around the fifty-year mark. Moreover, the effect is only statistically significant during the early years of an agency's life. This is indicated in the graph by the lower confidence interval falling below the reference line after the first seventeen years of observation. This initial period covers two-thirds of the observed terminations and is thus of substantive importance for the actual composition of the Swedish bureaucracy. Yet, the fact that the effect is not uniform over time also implies that there is a piece of the puzzle missing from the models.

As variations in "time" can hide all sorts of unobserved heterogeneity, it can be a precarious affair to give time-dependent coefficients a substantive interpretation. Moreover, the over-time variance is imprecisely estimated in all three models, which suggests that we may not want to put too much stock in the impact of the interaction terms. However, in this case, there are a number of theoretically relevant reasons for why we may nonetheless want to take the conditional effect seriously. The agencies most likely to endure over the long haul may, for instance, constitute a class of agencies working on issues where there is little to no conflict between the parties or feature some unobserved characteristic that make them particularly manipulable by the political incumbent. Alternatively, agencies may also grow increasingly resistant against political pressures the older they become (but see Carpenter and Lewis 2004). On the other hand, a binary measure of partisan shifts in government may also simply be too crude to adequately capture the actual level of conflict over the entire period, and in particular, conflict induced by shifting party priorities. For example, if 


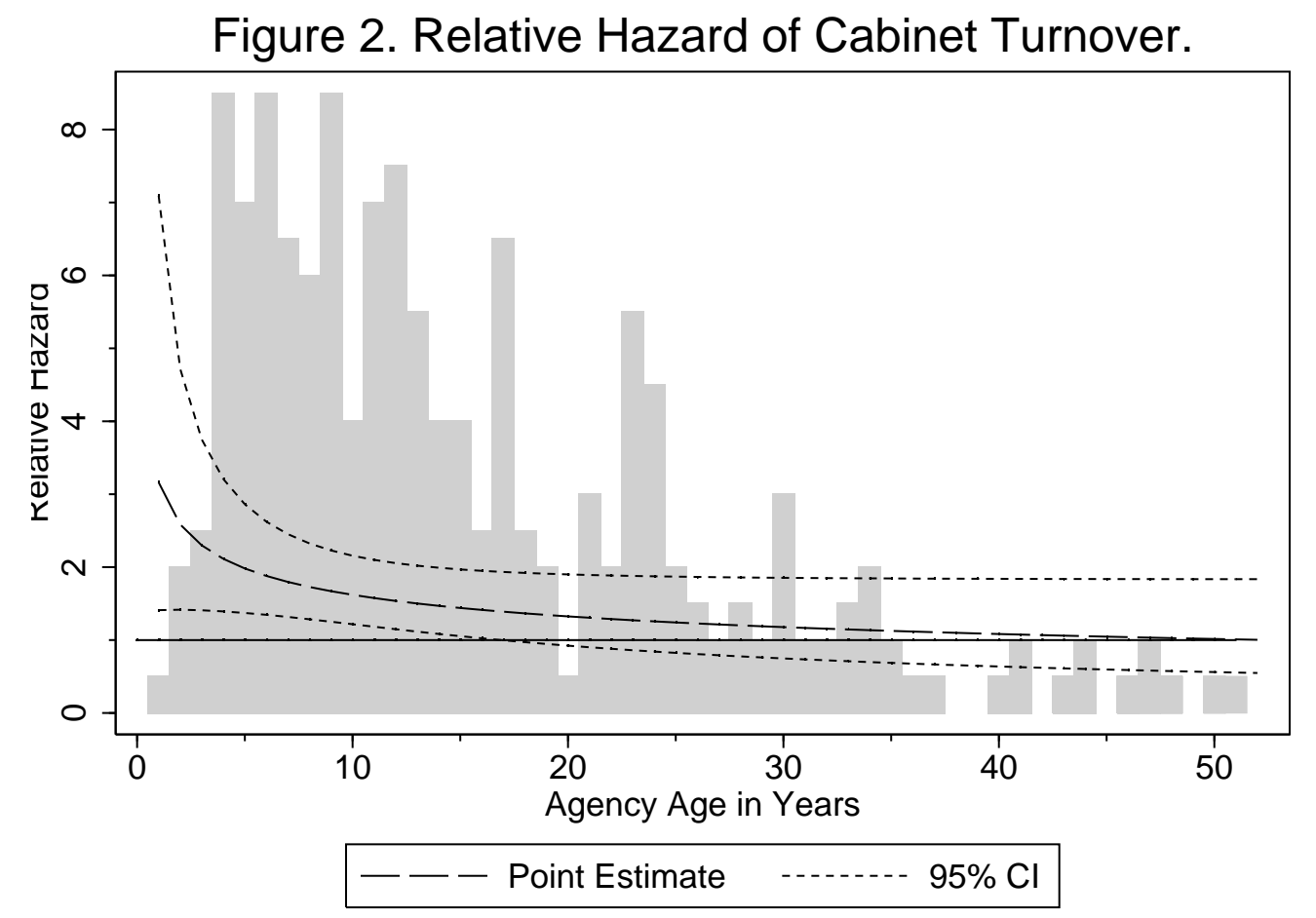

the policy positions of the Social Democratic Party in the 1990s are just as far away from the Social Democratic Party in the 1960s as they are from the right-wing bloc, then the effect of party conflict will be biased towards zero in the upper ranges of an agency's lifespan, generating a diminishing effect over time.

In model 5 to 7 , I use data on party manifestos (due to Volkens et al 2015) to examine how changes in a government's policy priorities can affect agency termination rates. The policy scale ranges from -10 to 10 . The maximum observed distance in the sample is 10.5 units, with a standard deviation of 2.1 units. In model 5 , which includes the policy conflict covariate along with the regression controls, the marginal effect of shifting the policy positions of either the enacting or sitting cabinets away from the other is an 8 percent increase in termination rates per unit. For reference, this means that a shift of 3.5 standard deviations would produce a point estimate of roughly the same size as the point estimate of party conflict in model 1. Unlike the party measure, however, the policy measure also allows for conflicts of interest within the respective blocs. For example, based on the data, the conservative Bildt cabinet (1991-1994) is located roughly two standard deviations from the social democratic Persson cab- 
Figure 3. Survival Function by Policy Incongruence.

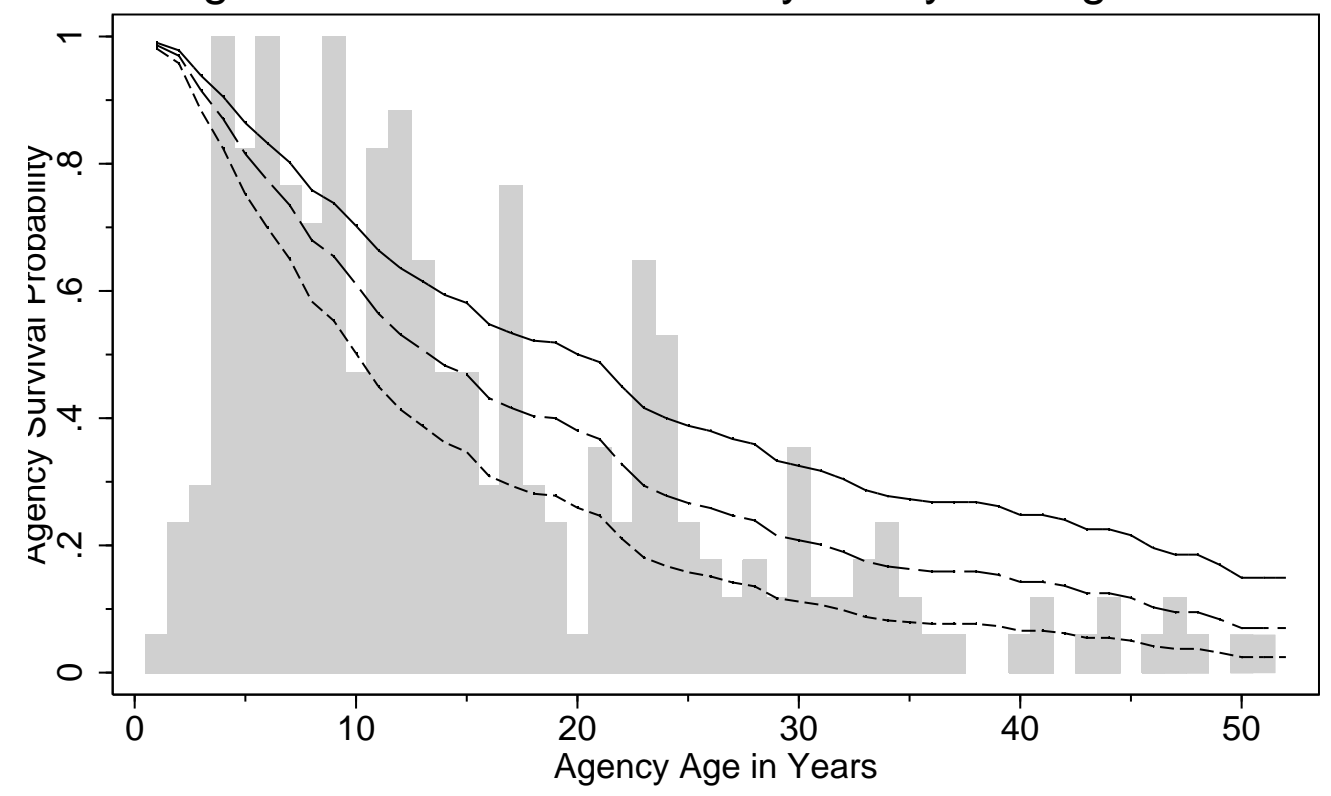

Shared Agendas $\quad--2$ Std. Dev.

4 Std. Dev.

inet (1998-2002) and four standard deviations from the social democratic Palme cabinet (1969-1974). However, two standard deviations also capture the distance between the conservative Bildt cabinet (1991-1994) and the conservative Reinfeldt cabinet (2006-2014), and four standard deviations the distance between the social democratic Erlander cabinet (1960-1964) and the social democratic Carlsson cabinet (1994-1996). Unlike model 1, furthermore, these models also all satisfy the proportional hazards assumption and, as can be seen from the regression output, the coefficients and standard errors also remain quite stable when adjusting for hierarchical clustering within the ministries.

To provide a better sense for what the models imply in absolute terms, I also plot the agency survival function in figure 3 (based on model 6 with all binary covariates at their modes and all continuous covariates at their means). The graph shows the estimated probability that an agency will endure beyond a certain age for different levels of policy conflict, with the survival probability on the $\mathrm{y}$-axis and the agency age on the $\mathrm{x}$-axis (i.e. an agency has a y percent chance of turning $x$ years old). The connected line traces the survival probability when the enacting and sitting cabinet occupy the same policy position, while the long- and short-dashed lines 
show analogous estimates for when they are two and four standard deviations away from each other, respectively. For example, the graph shows that, as long as the enacting and sitting cabinets have shared agendas, an agency has an estimated 50 percent chance of turning twenty years old. Shifting the policy positions of either side two standard deviations away from the other reduces the survival probability to a 50 percent chance of turning thirteen years old, while a shift of four standard deviations is associated with a 50 percent chance of turning ten years old. On the one hand, the survival function clearly highlights that agency termination is a rare event - even when there is a conflict of interest between the agency designer and the political incumbent. Going by the political performances during the past half century, it would likely take decades of uninterrupted rule for a given cabinet to completely replace an ideologically hostile bureaucracy. On the other hand, however, agencies are also much more likely to remain in operation for extended durations if they are accountable to coalitions with common interests, which provides strong support for the notion that partisan politics is one of the key drivers behind agency terminations.

While the statistical models are useful for describing general trends, Swedish political history is also rife with substantive examples of partisan conflicts over administrative institutions. When the Swedish Social Democrats enacted the Agency for School Development in 2003 to assist the municipalities in reaching national objectives and improving educational equality, for example, criticism was immediately raised by the liberal-conservative parties. In the education sector, they argued, central agencies should set national goals and evaluate results. School development, on the other hand, should be handled locally by teachers and school principals. Yet, as long as the Social Democrats maintained control of the cabinet, there was little for opponents of the agency to do but watch as it endured. Recognizing that administrative institutions are only as durable as the sitting coalition wants them to be, however, the opposition pledged to terminate the agency were they to gain office. And following the Social Democratic defeat in the 2006 general election, the agency was indeed terminated.

Some of the regression controls also suggest interesting relationships for future research, but a full discussion is beyond the scope of this article. Agencies with management boards or court-like functions appear particularly robust in all models, while rule-making or oversight functions appear 
less important. However, since the sample only includes agencies created between 1960 and 2014, the models may also be biased against a regulatory effect in virtue of excluding some of the most prominent regulatory agencies. The Central Bank of Sweden, for example, was created as far back as the 17th century, and a number of central social policy agencies such as the National Board of Health and Welfare during the first half of the 20th century. In comparison to the indicators of agency attributes, the indicators of economic and political conditions at the time of the sitting coalition perform less well. Although all four covariates have consistent signs across the models, only the ideological affiliation of the incumbent is estimated with enough precision to be distinguishable from zero, and only in models 5 to 7 .

\section{Conclusions}

Assuring successful delegation from elected representatives to unelected bureaucrats is an essential part of contemporary democratic governance and, to do so, politicians typically rely on administrative institutions that limit bureaucratic discretion - they impose procedures, personnel systems, monitoring mechanisms and sanctions that are designed to bias bureaucratic decision-making in their own favor. Precisely because institutions are designed with a view towards the future, however, any governing coalition that wishes to see their policy ambitions realized must also look to the past and deal with whatever administrative staff, structures and processes that previous coalitions have left for them. What they decide to do about the institutions they inherit, I suggest, often depends upon their ideological relations with those who designed the institution in the first place. When the partisan composition of the coalition that designed an institution diverges markedly from the coalition that decides its fate, an institution is particularly likely to be displaced; conversely, institutions turn increasingly robust as the partisan composition of the enacting and sitting coalitions converges.

To buttress this conjecture, I have traced the survival times of all administrative agencies enacted in the executive administration of Sweden between 1960 and 2014 and shown that agency termination rates increase markedly following partisan shifts in government. As in the US case, the politics of agency termination in Sweden appear strikingly consistent with 
the well-known ally principle in delegation theory (Bendor, Glazer, and Hammond 2001; Bendor and Meirowitz 2004). All else being equal, legislators become more inclined to delegate and grant discretion to an agency the closer the agency's policy preferences are to those of the legislative floor. And an agency is most likely to have policy preferences close to those of the legislative floor when its staff, structure and process have been defined by a legislative coalition whose partisan composition mirrors that of the sitting coalition. In this context, agency termination-properly understood as a special case of institutional choice -is simply an instrument for assuring that bureaucratic interests are aligned with those of the parties in power. In contrast to those who claim that political factors are typically irrelevant for understanding institutional choice in Europe (e.g. Yesilkagit and Christensen 2010), this article thus affirms that positive political theories of administrative design can be just as relevant for European parliamentary democracies as they are for the US system of separate powers.

Research on the relationship between partisan politics and institutional choice should not end here. This article has focused on the average effects of partisan shifts in government on agency termination rates. Yet such estimates may hide considerable variation. It is possible that sitting political leaders may sometimes be able to reconfigure an agency more to their liking by intervening in the screening and selection of the agency's personnel, for example, and the statistical models presented here do not consider how potential changes in the ideological leanings of individual bureaucrats may affect agency hazards. Even in the US case where we might expect institutional change to be relatively difficult to accomplish, agency designs are not static (Selin 2015). If ideologically hostile agencies can be easily captured after the fact, then focusing solely on political turnover since the time of enactment will miss much of the action. On the other hand, Moe and Caldwell (1994) have suggested that parliamentary governments can also increase the cost of future revisions by front-loading benefits, dispersing them widely among groups, and mobilizing an agency's clientele. Agencies that serve the interests of large and well-organized segments of the electorate and whose disappearance would be immediately felt may be better suited to resist partisan shifts in government than those serving only narrow interests or groups without representation in collective bargaining. Better measures of the linkages between political parties, interest groups and agencies would enable more accurate assessments of 
how deep into the bureaucracy partisan politics run, and would also provide insight into what - if anything - political leaders can do to insulate their policies in contexts where institutions and policies alike can be easily amended, as is typically the case in parliamentary democracies. In either case, the way forward for studies of agency terminations is surely to recognize that it is simply one instrument out of many that the parties in power can deploy to establish control over the bureaucracy.

The results of this paper also contribute to a foundation for further comparative work on the effects of different regime-types on the behavior of executive actors. Swedish parliamentary democracy departs from more conventional constitutional designs in three important ways. First, the fact that Swedish cabinets do not require active support from a parliamentary majority dulls the distinction between minority and majority governments. As long as a legislative coalition can demonstrate that no majority will rise against them, they gain full access to the government offices and all the powers contained therein, including the right to enact, reorganize and terminate executive agencies. Few constitutional designs outside the Nordic countries are as generous, however, and demands for larger coalitions should naturally present more opportunities for conflicts of interest both between the legislature and executive as well as within the executive itself. As Huber and Shipan (2002) argue, in parliamentary democracies where majority rule is a requirement for effective governance, coalition and minority government should be broadly analogous to divided government in the US. Second, Swedish ministers are constrained by collective decision-making within the cabinet, which ensures that all major decisions must be acceptable to the cabinet as a whole in order to gain traction. Turnover among individual ministers is thereby made into a minor concern because a change in portfolio ownership would only contribute marginally to the partisan composition of the cabinet in any case. However, in parliamentary systems with more independent ministers, one might expect to find ministerial turnover and preferences to be of relatively greater importance in the politics of institutional choice (James et al 2015). Third, Sweden also employs a rather strict constitutional separation between politics and administration, with limited opportunities for politicians to manage agency personnel and review agency policy choices. To the extent that Swedish political leaders want to leave their mark on public administration and steer policy implementation, the incentives are 
thus stacked in favor of just the sort of structural interventions that have been the focus of this paper. In systems with less rigid civil service restrictions on personnel management, one might however expect the power of appointment to make structural reorganization lose some of its luster, thereby generating more stable bureaucratic structures, but at the cost of higher turnover rates among agency personnel. The literature provides ample reason to expect different behaviors under different constitutional arrangements, but efforts to assess such claims empirically remain sparse.

Finally, this article brings further evidence that those who hold public bureaucracies to be essentially immutable should revisit their conclusions. Ever since the classic works of Weber, many have taken for granted that bureaucratic structures by their very nature are some of the hardest to destroy. Yet, the evidence at hand suggests that the prospect of an agency enduring over the long haul varies systematically with changes in the political environment: When the bargaining position of the partisan coalitions that were in power at the time of enactment falters, so too does the durability of their creations. Future studies would do well to further explore how bureaucracies can be endogenously generated by political struggles over the exercise of public authority.

\section{References}

Ahlbäck öberg, Shirin and Helena Wockelberg. 2015. "The Public Sector and the Courts." In The Oxford Handbook of Swedish Politics, ed., Pierre, Jon. Oxford: Oxford University Press.

Ahrland, Karin. 1983. "Nej, fru statsråd!" Statsvetenskaplig Tidsskrift 65: $145-152$

Allison, Paul. 2009. Fixed Effects Regression Models. Los Angeles: Sage. Bach, Tobias and Sylvia Veit. 2017. "The Determinants of Promotion to High Public Office in Germany: Partisan Loyalty, Political Craft, or Managerial Competencies?" Journal of Public Administration Research and Theory https://doi.org/10.1093/jopart/mux041

Bawn, Kathleen. 1995. "Political Control versus Expertise: Congressional Choices about Administrative Procedures." American Political Science Review 89 (1): 62-73

Bendor, Jonathan and Adam Meirowitz. 2004. "Spatial Models of Delegation." American Political Science Review 98 (2): 293-310. 
Bendor, Jonathan, Ami Glazer and Thomas Hammond. 2001. "Theories of Delegation." Annual Review of Political Science 4: 477-496.

Bergman, Torbjörn. 2003. "Sweden: From Separation of Powers to Parliamentary Supremacy — and Back Again?" In Delegation and Accountability in Parliamentary Democracies, eds., Strøm, Kaare, Wolfgang Mller and Torbjörn Bergman. Oxford: Oxford University Press.

Bertelli, Anthony and David Lewis. 2012. "Policy Influence, AgencySpecific Expertise, and Exits in the Federal Service." Journal of Public Administration Research and Theory 23 (2): 223-245

Bertelli, Anthony and Andrew Sinclair. 2016. "Democratic Accountability and the Politics of Mass Administrative Reform." British Journal of Political Science. https://doi.org/10.1017/S0007123416000077

Berry, Christopher, Barry Burden and William Howell. 2010. "After Enactment: The Lives and Deaths of Federal Programs." American Journal of Political Science 54 (1): 1-17.

Box-Steffensmeier, Janet and Bob Jones. 2004. Event History Modeling: A Guide for Social Scientists. New York: Cambridge University Press. Carpenter, Daniel and David Lewis. 2004. "Political Learning from Rare Events: Poisson Inference, Fiscal Constraints, and the Lifetime of Bureaus." Political Analysis 12: 201-232.

Clinton, Joshua, Anthony Bertelli, Christian Grose, David Lewis and David Nixon. 2012. "Separated Powers in the United States: The Ideology of Agencies, Presidents, and Congress." American Journal of Political Science 52 (2): 341-354

Dahlström, Carl and Birgitta Niklasson. 2013. "The Politics of Politicization in Sweden." Public Administration 9 (4): 891-907.

Dahlström, Carl and Mikael Holmgren. 2017. "The Political Dynamics of Bureaucratic Turnover." British Journal of Political Science. https://doi.org/10.1017/S0007123417000230

Downs, Anthony. 1967. Inside Bureaucracy. Boston: Little Brown

Ennser-Jedenastik, Laurenz. 2016. "The Politiciziation of Regulatory Agencies: Between Partisan Influence and Formal Independence." Journal of Public Administration Research and Theory 26 (3): 507518

Epstein, David and Sharyn O'Halloran. 1999. Delegating Powers. A Transaction Cost Politics Approach to Policy Making under Separate Powers. New York: Cambridge University Press. 
Esaiasson, Peter, Mikael Persson, Mikael Gilljam and Torun Lindholm. 2016. "Reconsidering the Role of Procedures for Decision-Acceptance." British Journal of Political Science. https://doi.org/10.1017/S0007123416000508 de Figueiredo, Rui. 2002. "Electoral Competition, Political Uncertainty, and Policy Insulation." American Political Science Review 96 (2): 321-333 Gailmard, Sean and John Patty. 2012. Learning While Governing: Expertise and Accountability in the Executive Branch. Chicago: The University of Chicago Press

Christensen, Tom and Per Laegreid. Eds. 2003. New Public Management: The Transformation of Ideas and Practice. Ashgate: Eldershot.

Greasley, Stephen and Chris Hanretty. 2016. "Credibility and Agency Termination under Parliamentarism." Journal of Public Administration Research and Theory 26 (1): 159-173

Horn, Murray and Kenneth Shepsle. 1989. "Commentary on "Administrative Arrangements and the Political Control of Agencies": Administrative Process and Organizational Form as Legislative Responses to Agency Costs" Virginia Law Review 75 (2): 499-508

Hougaard, Phillip. 2000. Analysis of Multivariate Survival Data. New York: Springer.

Howell, William and David Lewis. 2002. "Agencies by Presidential Design." Journal of Politics 64 (4): 1095-1114

Huber, Evelyne and John Stephens. 2001. Development and Crisis of the Welfare State. University of Chicago Press: Chicago and London

Huber, John and Charles Shipan. 2002. Deliberate Discretion? The Institutional Foundations of Bureaucratic Autonomy. New York: Cambridge University Press.

Jacobsson, Bengt, Göoran Sundström and Jon Pierre. 2015. Governing the Embedded State: The Organizational Dimension of Governance. Oxford: Oxford University Press.

James, Oliver, Nicolai Petrovsky, Alice Moseley and George Boyne. 2015. "The Politics of Agency Death: Ministers and the Survival of Government Agencies in a Parliamentary System." British Journal of Political Science 46 (4): 763-784

Kaufman, Herbert. 1976. Are Government Organizations Immortal? Washington, DC: Brookings Institution.

Kiewiet, Rodney and Mathew McCubbins. 1991. The Logic of Delegation: Congressional Parties and the Appropriations Process. Chicago: 
University of Chicago Press.

Lancaster, Tony. 1979. "Econometric Methods for the Duration of Unemployment." Econometrica 47 (4): 939-956

Levin, Bert. 1983. "En skog av röda nlar. Om politiseringen av department och förvaltning." In Makt och vanmakt, ed. Bengt Rydn. Stockholm: SNS.

Lewis, David. 2002. "The Politics of Agency Termination: Confronting the Myth of Immortality." Journal of Politics 64: 89-107.

Lewis, David. 2004. "The Adverse Consequences of the Politics of Agency Design for Presidential Management in the United States: The Relative Durability of Insulated Agencies." British Journal of Political Science 34 (3): 377-404.

Lewis, David. 2008. The Politics of Presidential Appointments. New Jersey: Princeton University Press.

Licht, Amanda. 2011. "Change Comes with Time: Substantive Interpretation of Nonproportional Hazards in Event History Analysis." Political Analysis 19 (2): 227-243

Lindbom, Anders. 2008. "The Swedish Conservative Party and the Welfare State: Institutional Change and Adapting Preferences." Government and Opposition 43 (4): 539-560

Lowi, Theodore. 1979. The End of Liberalism. New York: W. W. Norton and Company.

Lupia, Arthur and Kaare Strøm. 2008. "Bargaining, Transaction Costs, and Coalition Governance." In Cabinets and Coalition Bargaining: The Democratic Life Cycle in Western Europe, eds. Kaare Strøm, Wolfgang Mller, and

Torbjörn Bergman. Oxford: Oxford University Press

McCubbins, Mathew and Thomas Schwartz. 1984. "Congressional Oversight Overlooked: Police Patrols versus Fire Alarms." American Journal of Political Science 28: 165-179.

McCubbins, Mathew, Roger Noll, and Barry Weingast. 1987. "Administrative Procedures as Instruments of Political Control." Journal of Law, Economics, \& Organization 3 (2): 243-277.

McCubbins, Mathew, Roger Noll, and Barry Weingast. 1989. "Structure and Process, Politics and Policy: Administrative Arrangements and the Political Control of Agencies." Virginia Law Review 75 (2): 431482 
Moe, Terry. 1984. "The New Economics of Organization". American Journal of Political Science 28 (4): 739-777.

Moe, Terry. 1985. "Control and Feedback in Economic Regulation: The Case of the NLRB." American Political Science Review 79 (4): 10941116

Moe, Terry. 1989. "The Politics of Bureaucratic Structure." In Can the Government Govern?, eds. John Chubb and Paul Peterson. Washington, DC: The Brookings Institution.

Moe, Terry. 1990. "Political Institutions: the Neglected Side of the Story." Journal of Law, Economics, \& Organization 6: 213-253.

Moe, Terry. 2012. "Delegation, Control, and the Study of Public Bureaucracy." In The Handbook of Organizational Economics, eds. Robert Gibbons and John Roberts. Princeton and Oxford: Princeton University Press

Moe, Terry and Michael Caldwell. 1994. "The Institutional Foundations of Democratic Government: A Comparison of Presidential and Parliamentary Systems." Journal of Institutional Theoretical Economics 150 (1): 171-195.

Painter, Martin and Guy Peters, eds. 2010. Tradition and Public Administration. London: Palgrave Macmillan.

Patashnik, Eric. 2003. "After the Public Interest Prevails: The Political Sustainability of Policy Reform." Governance 16 (2): 203-234

Pierre, Jon. 1995. "Governing the Welfare State: Public Administration, the State, and Society in Sweden." In Governing the Modern State: An Introduction to Comparative Public Administration, eds Jon Pierre. Aldershot: Edward Elgar

Pollit, Christopher and Geert Bouckaert. 2004. Public Management Reform: A Comparative Perspective. Oxford: Oxford University Press

Riker, William. 1980. "Implications from the Disequilibrium of Majority Rule for the Study of Institutions." American Political Science Review 74 (2): 432-446

Rothstein, Bo. 1996. The Social Democratic State: The Swedish Model and the Bureaucratic Problem of Social Reforms. Pittsburgh: University of Pittsburgh Press

Selin, Jennifer. 2015. "What Makes an Agency Independent?" American Journal of Political Science 59 (4): 971-987

Shepsle, Kenneth. 1992. "Bureaucratic Drift, Coalitional Drift, and Time 
Consistency: A Comment on Macey." Journal of Law, Economics \& Organization 8: 111-118

Shepsle, Kenneth. 2008. "Old Questions and New Answers about Institutions: The Riker Objection Revisited" In The Oxford Handbook of Political Economy, eds. Donald Wittman and Barry Weingast. Oxford: Oxford University Press

Strøm, Kaare. 2000. "Delegation and Accountability in Parliamentary Democracies." European Journal of Political Research 37 (3): 261290

Strøm, Kaare, Wolfgang Mller, and Torbjörn Bergman, eds. 2003. Delegation and Accountability in Parliamentary Democracies. Oxford: Oxford University Press.

Volkens, Andrea, Pola Lehmann, Theres Matthies, Nocals Merz, Sven Regel, and Annika Wener. 2015. The Manifesto Data Collection. Manifesto Project (MRG/CMP/MARPOR). Version 2015a. Berlin: Wissenschaftszentrum Berlin fr Sozialforschung.

Weber, Max. 1978. Economy and Society. Berkeley: University of California Press.

Weingast, Barry and Michael Moran. 1983. "Bureaucratic Discretion or Congressional Control? Regulatory Policymaking by the Federal Trade Commission." Journal of Political Economy 91: 765-800.

Wood, Dan and John Bohte. 2004. "Political Transaction Costs and the Politics of Administrative Design." Journal of Politics 66 (1): 176-202 Yesilkagit, Kutsal and Jørgen Christensen. 2010. "Institutional Design and Formal Autonomy: Political versus Historical and Cultural Explanations." Journal of Public Administration Research and Theory $20(1): 53-74$ 